\title{
Dietary Houttuynia Cordata/Fermented Red Koji Blends to Improve Duck Growth Performance and Alum Blends Addition to Reduce Litter Ammonia Concentration
} W.W JANG ${ }^{*}$, T.H. CHUNG ${ }^{2}$, I. H. CHOI $^{2 *}$

${ }^{1}$ Department of Agricultural economics, Kyungpook National University, Daegu, 41566, South Korea; ${ }^{2}$ Department of Companion Animal \& Animal Resources Science, Joongbu University, Geumsan-gun, 32713, South Korea.

\begin{abstract}
We investigated the effects of different formulations of the herb Houttuynia cordata (HC) mixed with fermented red koji (FRK) as feed additives on the growth performance of ducks and the effects of adding chemical blends (alum and $\mathrm{AlCl}_{3}$ ) on the $\mathrm{pH}$ and ammonia $\left(\mathrm{NH}_{3}\right)$ concentration of duck litter. After a 2-week brooding period, 240 one-day-old Peking ducks (160 male and 80 female) were allocated to one of four dietary groups (control, 1\% HC powder mixed with FRK, pelleted 1\% HC/FRK, and coated pellets of 1\% HC/FRK), each with four replicates of 15 birds, and four chemical blend litter treatments (control, $50 \mathrm{~g}$ alum $+50 \mathrm{~g} \mathrm{AlCl}, 100 \mathrm{~g}$ alum $+100 \mathrm{~g} \mathrm{AlCl}$, and $150 \mathrm{~g}$ alum $+150 \mathrm{~g} \mathrm{AlCl} / 3 \mathrm{~kg}$ duck litter) in the pens used for feeding trials. In terms of growth performance, we found that final body weight, weight gain, feed intake, and feed conversion ratio varied significantly among birds fed the different HC diets $(P<0.05)$. Duck litter $\mathrm{pH}$ differed significantly during the experimental period $(P<0.05)$, except during days 28. The additive blends had a strong influence $(P<0.05)$ on $\mathrm{NH}_{3}$ throughout the experimental period (not on day 7$)$. In conclusion, adding $1 \% \mathrm{HC}$ (in pellets and coated-pellet form) with FRK to duck diets improved growth performance and the inclusion of chemical blends (a combination of $50 \mathrm{~g}$ alum and $50 \mathrm{~g} \mathrm{AlCl}_{3}$ per $\mathrm{kg}$ litter as optimal rate) in duck litter in pens during the feeding trial decreased litter $\mathrm{NH}_{3}$ concentration and $\mathrm{pH}$.
\end{abstract}

Keywords | Ammonia, Chemical blend, Duck litter, Feed additive, Growth performance.

\footnotetext{
Received | June 25, 2019; Accepted | August 19, 2019; Published | November 26, 2019

*Correspondence | I.H. Choi, Department of Companion Animal \& Animal Resources Science, Joongbu University, Geumsan-gun, 32713, South Korea; Email: wicw@chol.com

Citation | Jang WW, Chung TH, Choi IH (2019). Dietary houttuynia cordata/fermented red koji blends to improve duck growth performance and alum blends addition to reduce litter ammonia concentration. Adv. Anim. Vet. Sci. 7(12): 1101-1106.

DOI | http://dx.doi.org/10.17582/journal.aavs/2019/7.12.1101.1106
}

ISSN (Online) | 2307-8316; ISSN (Print) | 2309-3331

Copyright (c) 2019 Jang et al. This is an open access article distributed under the Creative Commons Attribution License, which permits unrestricted use, distribution, and reproduction in any medium, provided the original work is properly cited.

\section{INTRODUCTION}

$\mathrm{M}$ edicinal herbs possess multiple unique properties and have several beneficial effects as feed additives, notably the enhancement of growth performance in animals (Fu et al., 2013). Recently, the livestock industry has begun using appetite-stimulating medicinal herbs as feed additives to promote growth (Costa et al., 2013; Paraskeuas et al., 2017). One such herb is the chameleon plant Houttuynia cordata (HC), which is widely distributed in southeast Asia, where it grows on shady hillsides, waysides, and field margins across a wide altitudinal range (300-2600 m) (Fu et al., 2013). The plant has been used in traditional medicine for various pharmacological benefits, including its antioxidant and anti-inflammatory effects (Jiang and Cui, 2004; Toda, 2005; Lu et al., 2006; Muluye et al., 2014). The beneficial properties of $\mathrm{HC}$ are attributable to its principal bioactive compounds, including phenols, essential oils, and flavonoids (Bauer et al., 1996; Lee et al., 2008). In livestock studies, powdered HC extract (1\%) has been found to increase growth performance (Yan et al., 2011). A further promising feed additive for enhancing livestock growth performance is red koji (Monascus sp.). This fungus is used as a dietary supplement or herbal medication in East Asian countries due to its production of cholesterol-decreasing monacolin K (Fujimoto et al., 2012). In addition to this potential advantage, several reports have indicated that red koji is also a source of $\gamma$-aminobutyric acid, a hypotensive agent, and dimerumic acid, an antioxidant (Aniya et al., 2000; Su et al., 2003; Darwish et al., 2017). Despite the apparent benefits of both additives, however, few studies have evaluated the combined effects of $\mathrm{HC}$ and fermented 
red koji (FRK) on the growth of ducks. In addition to increasing productivity, another major concern in the livestock industry is reducing the emission of ammonia $\left(\mathrm{NH}_{3}\right)$ gas from litter and manure. The release of $\mathrm{NH}_{3}$ within poultry facilities markedly elevates atmospheric ammonia concentrations, thereby contributing to health problems in both birds and workers (David et al., 2015). Poultry studies have shown that $\mathrm{NH}_{3}$ at a concentration of $25 \mathrm{ppm}$ negatively affects production (Miles et al., 2006; Olanrewaju et al., 2007). Several acidulants are used to inhibit $\mathrm{NH}_{3}$ flux through reduction of manure $\mathrm{pH}$ and suppression microbial activities. The effects of the aluminum sulfate (alum) and liquid aluminum chloride on $\mathrm{NH}_{3}$ concentration have been well documented (Moore et al., 2000; Choi and Moore, 2008). Currently, however, there is little data available on the efficacy of acidulant blends in reducing the $\mathrm{NH}_{3}$ concentration of duck litter. Thus, this study, examined the influence of different preparations of $\mathrm{HC}$ mixed with FRK, and the addition of acidulent blends on duck growth and litter $\mathrm{pH}$ and $\mathrm{NH}_{3}$ concentration.

\section{MATERIAL AND METHODS}

\section{Preparation of Different Types of HC/FrK Combinations}

HC leaves and FRK were obtained from Yusim Co. (Yeongju, Korea). The leaves were air-dried at room temperature for $12 \mathrm{~h}$ and then hot-air-dried at $50-60^{\circ} \mathrm{C}$ for two consecutive days before being ground to a fine powder (1 $\mathrm{mm}$ ). The powder was then thoroughly mixed with FRK in a 9:1 powder-to-koji ratio. Subsequently, we used a pellet machine (Kum Kang Eng., Daegu, South Korea) to manufacture pellets of the HC/FRK blend. Some of these pellets were then coated via spraying with canola oil (improving growth performance) using a small hand pump and dried for $7 \mathrm{~d}$. These various forms of feed additives were stored separately in plastic bags and refrigerated until needed for the experiment.

\section{Experimental Design ANd Animals}

The animal care and experimental protocols used in this study were approved by the animal care committee of Gilhong farm (Geochang, South Korea). In this study, both chemical treatment and dietary trials were simultaneously performed at the same pens. Total pens used in this study were 16 pens. After a 2 -week brooding period, 240 oneday-old Peking ducks (160 male and 80 female) were allocated to one of four dietary treatments. Each treatment lasted $38 \mathrm{~d}$ and contained four replicates of 15 birds (10 male and 5 female) in a completely randomized design. The diets supplied were as follows: (1) basal diet (Control) in pen with no alum or aluminum; (2) T1, basal diet $+1 \%$ $\mathrm{HC}$ powder mixed with FRK in pen with $50 \mathrm{~g}$ alum + $50 \mathrm{~g}$ aluminum chloride/kg duck litter; (3) T2, basal diet
+ pelleted $1 \% \mathrm{HC} / \mathrm{FRK}$ in pen with $100 \mathrm{~g}$ alum + $100 \mathrm{~g}$ aluminum chloride/kg duck litter; and (4) T3, basal diet + coated pellets of $1 \% \mathrm{HC} / \mathrm{FRK}$ in pen with $150 \mathrm{~g}$ alum $+150 \mathrm{~g}$ aluminum chloride/kg duck litter. The standard industrial diets (basal diets) used in this study were provided in two phases: starter diet (0-21 d of age; $21 \%$ crude protein, $2.5 \%$ crude fat, $8 \%$ crude fiber, and $9 \%$ crude ash) and finisher diet (22-38 d of age; $17 \%$ crude protein, $2.5 \%$ crude fat, $8 \%$ crude fiber, and $9 \%$ crude ash). Each pen (2.5 $\mathrm{m} \times 2 \mathrm{~m}$ ) was supplied with a feeder and a drinker for $a d$ libitum access to feed and water during the experimental period. The duck facility used in the study has an automatic ventilation and temperature system. Ducks were initially reared at $33^{\circ} \mathrm{C}$ for $14 \mathrm{~d}$ before the temperature was gradually decreased to $23^{\circ} \mathrm{C}$, which was maintained until the end of the experiment. Body weight, feed intake, weight gain, and feed conversion ratio per pen were determined for the entire experimental period. Body weight gain was calculated based on body weight measurements from day 14 to day 38 (end of the experiment). Feed intake was determined from daily measurements of residual feed throughout the experimental period. Feed conversion ratio was calculated as feed intake divided by weight gain.

\section{Chemical Treatment and $\mathrm{PH}$ and $\mathbf{N H}_{3}$} Measurement

Approximately $8 \mathrm{~cm}$ of duck litter (a mixture of rice hulls and duck manure) was deposited over the concrete flooring of the duck pens. Alum and aluminum chloride $\left(\mathrm{AlCl}_{3}\right)$ were purchased from the Daejung Chemicals and Metals Company (Siheung, South Korea). The litter-additive experiment was a completely randomized design of four treatments, with four replications each in the same pens used for feeding trials. The treatments were as follows: (1) control, no additives in pen with basal diet; (2) T1, $50 \mathrm{~g}$ alum $+50 \mathrm{~g}$ aluminum chloride $/ \mathrm{kg}$ duck litter in pen with $1 \% \mathrm{HC}$ powder mixed with FRK; (3) T2, $100 \mathrm{~g}$ alum + 100 $\mathrm{g}$ aluminum chloride/kg duck litter in pen with pelleted $1 \% \mathrm{HC} / \mathrm{FRK}$; and 4) T3, $150 \mathrm{~g}$ alum $+150 \mathrm{~g}$ aluminum chloride $/ \mathrm{kg}$ duck litter in pen with coated pellets of $1 \%$ HC/FRK. These blends were applied as top-dressing on the litter before starting 7 days of duck placement. Litter samples $(100 \mathrm{~g})$ were collected weekly $(12: 00 \mathrm{pm})$ from five different locations in each pen. The samples collected from each pen were manually mixed as thoroughly as possible. To prevent potential cross contamination, fresh latex gloves were worn when mixing the litter collected from the different pens (Stanley et al., 2004). Mixed samples were stored in sealed plastic bags and refrigerated until needed for $\mathrm{pH}$ analysis. To determine $\mathrm{pH}, 20 \mathrm{~g}$ of litter was added to a $250-\mathrm{mL}$ polycarbonate centrifuge tube containing 200 $\mathrm{mL}$ deionized water, then agitated in a mechanical shaker for $2 \mathrm{~h}$ before centrifuging at $6000 \mathrm{rpm}$ for $15 \mathrm{~min}$, following Moore et al. (1995). Immediately thereafter, the $\mathrm{pH}$ of the unfiltered sample was measured using a digital $\mathrm{pH}$ 
Table 1: Performance of duck fed diets with different types of H.cordata with fermented red koji during 38 days

\begin{tabular}{|c|c|c|c|c|c|c|}
\hline \multirow[t]{2}{*}{ Parameters } & \multicolumn{4}{|c|}{ Treatment $^{1}$} & \multirow[t]{2}{*}{ SEM $^{2}$} & \multirow[t]{2}{*}{ p-value } \\
\hline & Control & T1 & T2 & T3 & & \\
\hline Initial body weight (14 d, g) & 364.75 & 359.00 & 346.50 & 352.25 & 3.94 & 0.3194 \\
\hline Final body weight (38 d, g) & $2770.50^{c}$ & $2847.75^{\mathrm{b}}$ & $2841.75^{\mathrm{b}}$ & $2937.75^{a}$ & 34.22 & 0.0009 \\
\hline Weight gain (g) & $2405.75^{c}$ & $2488.75^{b}$ & $2495.25^{\mathrm{b}}$ & $2585.50^{\mathrm{a}}$ & 36.78 & 0.0007 \\
\hline Feed intake (g) & $5030.25^{a}$ & $4795.25^{\mathrm{bc}}$ & $4750.50^{c}$ & $4840.25^{\mathrm{b}}$ & 33.88 & 0.0022 \\
\hline $\begin{array}{l}\text { Feed conversion ratio } \\
\text { ( } \mathrm{g} \text { feed/g gain) }\end{array}$ & $2.09^{a}$ & $1.93^{\mathrm{b}}$ & $1.90^{\mathrm{bc}}$ & $1.87^{\mathrm{c}}$ & 0.25 & 0.0001 \\
\hline
\end{tabular}

${ }^{a-c}$ Means in the same rows with no common superscript are significantly different $(P<0.05)$.

${ }^{1}$ Control: basal diet in pen with no alum or aluminum; T1: basal diet + 1\% HC powder mixed with FRK in pen with $50 \mathrm{~g}$ alum + $50 \mathrm{~g}$ aluminum chloride/kg duck litter; T2: basal diet + pelleted 1\% HC/FRK in pen with $100 \mathrm{~g}$ alum + $100 \mathrm{~g}$ aluminum chloride/ $\mathrm{kg}$ duck litter; T3: basal diet + coated pellets of $1 \% \mathrm{HC} / \mathrm{FRK}$ in pen with $150 \mathrm{~g}$ alum $+150 \mathrm{~g}$ aluminum chloride/kg duck litter.

${ }^{2}$ Values are expressed as means \pm standard errors.

meter (691 pH meter; Metrohm, Switzerland). Additionally, the $\mathrm{NH}_{3}$ concentration of the duck litter was measured weekly $(10: 00 \mathrm{am})$ above the litter surface $(2 \mathrm{~cm})$ using gas-tech (Gas Tech Corporation, Fukaya, Ayase, Japan) with ammonia kit at four random sites within pen at interval of $60 \mathrm{~s}$.

\section{Statistical Analysis}

All data were subjected to analysis of variance (ANOVA) using the general linear model (GLM) procedure in SAS (SAS Institute 2000). A pen was considered the experimental unit for growth performance, $\mathrm{pH}$, and ammonia flux analysis. Significant $(p<0.05)$ between-treatment differences in means were determined using Tukey's tests.

\section{RESULTS AND DISCUSSION}

\section{Growth Performance}

Table 1 depicts the result of growth performance with different types of HC/FRK combinatio ns. All feed additive treatment significantly $(p<0.05)$ affected the growth performance (final body weight, weight gain, feed intake, and feed conversion ratio) of ducks. Overall, final body weight and weight gains were significantly higher in birds fed the coated pellets (T3) than in the other treatments. Also, ducks provided with coated pellets (T3) and pelleted 1\% HC/FRK (T2) had significantly improved feed conversion ratios compared with those in the other treatment groups $(p<0.05)$. However, birds fed the control diet had higher feed intake and feed conversion ratio or lower weight gain than those in the other treatment groups. In general, the use of herb additives or herbal extracts increases feed flavor and palatability, and can thereby contribute to improving growth performance (Karásková et al., 2015).

Unfortunately, differences in herb quality and variation in the selected herbs have led to largely inconsistent results in studies that have examined the effects of diets containing phytogenic feed additives (Windisch et al., 2008). For example, feed levels and growth period have both been found to affect the phytogenic efficiency of herbal additives in broiler chickens (Mountzouris et al., 2011). In other studies, the addition of herbal antioxidant supplements (Aonla, Tulsi, and Satawari) in the diet of broiler chicks significantly affected broiler growth rate (but not feed consumption) (Singh et al., 2017).

In the present study, we found that the form in which the HC + FRK additive was provided to ducks had a differential effect on the improvement in growth performance in following order: coated pellets (T3) $>$ pellets $(\mathrm{T} 2)>$ powder blend (T1) > Control. The differences in the growth promoting effects of $H$. cordata and red koji could explained by three factors: i) the presence of bioactive compounds, ii) the use of canola oil (an essential oil), and iii) the different forms of the additive. In other words, the selected herbal ingredients included bioactive compounds with intrinsic properties that can enhance effective feed utilization (Rao et al., 2003; Saha et al., 2011). Essential oils also have phytobiotic properties and can therefore stimulate digestive enzyme secretion, thereby improving growth and feed utilisation (Jang et al., 2004). Finally, the ability of poultry to select feed particles according to their beak size, increases with age thus, older poultry tend to prefer larger feed particle sizes (Favero et al., 2009). These findings are in line with those of a previous study on broiler chickens that revealed a beneficial effect of herbal products $(952 \mathrm{mg} /$ $\mathrm{kg}$ of coriander extract in drinking water) on body weight gain (Naeemasa et al., 2015). Similarly, addition of $2 \%$ HC powder has previously been observed to beneficially influence growth performance in ducks (Chung and Choi, 2015).

\section{LitTer Ph and Ammonia Concentration}

Litter $\mathrm{pH}$ and ammonia concentration as a function of time are presented in Figure 1. Duck litter $\mathrm{pH}$ differed significantly across treatments $(P<0.05)$, except during days 
A
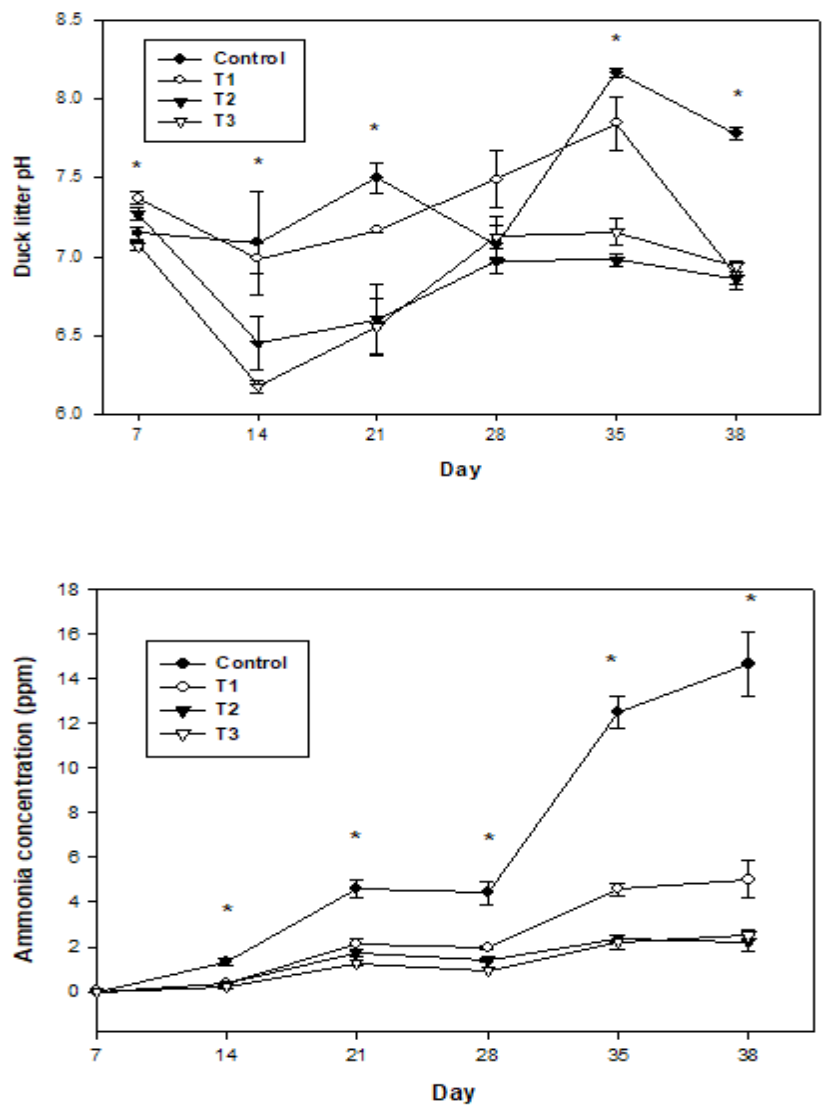

Figure 1: Effects of the addition of chemical blends to duck litter on A) litter $\mathrm{pH}$; and $\mathrm{B}$ ) ammonia concentration as a function of time. Treatments included:Control, no additives in pen with basal diet; T1, $50 \mathrm{~g}$ alum $+50 \mathrm{~g}$ aluminum chloride/ $\mathrm{kg}$ duck litter in pen with $1 \% \mathrm{HC}$ powder mixed with FRK; T2, $100 \mathrm{~g}$ alum + $100 \mathrm{~g}$ aluminum chloride/kg duck litter in pen with pelleted 1\% HC/FRK; and T3, 150 $\mathrm{g}$ alum $+150 \mathrm{~g}$ aluminum chloride/kg duck litter in pen with coated pellets of $1 \% \mathrm{HC} / \mathrm{FRK}$.* indicates significant differences at $P<0.05$.

28 (Figure 1A). During days 7, the initial $\mathrm{pH}$ values across all treatments ranged from 7.07 to 7.37. Control litter $\mathrm{pH}$ was $7.09,7.50,7.08,8.17$, and 7.78 on days $14,21,28$, 35 , and 38 , respectively. Over time, the mean $\mathrm{pH}$ values of litter treated with the three different experimental blends varied from 6.18 to 7.85 . Litter treatments significantly influenced the $\mathrm{NH}_{3}$ concentration during the experimental period $(P<0.05)$, except on day $7(P>0.05)$. During these first 14 days, the $\mathrm{NH}_{3}$ concentration in all treatments was below $1.50 \mathrm{ppm}$. In the control litter, the $\mathrm{NH}_{3}$ concentration on days $21,28,35$, and 38 was 4.63, 4.41, 12.50, and $14.69 \mathrm{ppm}$, respectively. Over time, the three litter treatments increased $\mathrm{NH}_{3}$ concentration from 1.27 to $5 \mathrm{ppm}$. As shown in Figure $1 \mathrm{~B}, \mathrm{Al}$ products reduce $\mathrm{NH}_{3}$ concentration compared to the control. In comparison with three litter treatments, there is no remarkable difference between
T2 (100 g alum + $100 \mathrm{~g} \mathrm{AlCl}$ per kg duck litter) and T3 (150 g alum + $150 \mathrm{~g} \mathrm{AlCl}$ per kg duck litter) for ammonia concentration. Overall, the litter treatments tended to decrease the $\mathrm{pH}$ value and $\mathrm{NH}_{3}$ concentration of litter compared with control litter. After 38 days, the $\mathrm{NH}_{3}$ concentration of litter had decreased by $62 \%, 80 \%$, and $84 \%$ in response to the application of $50 \mathrm{~g}$ alum $+50 \mathrm{~g} \mathrm{AlCl}_{3}, 100$ $\mathrm{g}$ alum $+100 \mathrm{~g} \mathrm{AlCl}$, and $150 \mathrm{~g}$ alum $+150 \mathrm{~g} \mathrm{AlCl}_{3}$ per kg duck litter, respectively. These results corroborate the findings of a study showing that the addition of an anhydrous $\mathrm{AlCl}_{3}$ and $\mathrm{CaCO}_{3}$ mix to broiler litter reduced the $\mathrm{NH}_{3}$ flux by $55.3 \%, 56.4 \%, 40.1 \%$, and $35.8 \%$ after 1,2 , 3, and 4 weeks, respectively (Lee et al., 2013).

In the present study, our monitoring of duck litter properties indicated that increasing application of the chemical blend lowered $\mathrm{pH}$ and $\mathrm{NH}_{3}$ content. The application of appropriate litter amendments can create an acidic environment unfavorable for the microbial and enzymatic activities involved in $\mathrm{NH}_{3}$ formation ( $\mathrm{Li}$ et al., 2008; Pokharel, 2010). Especially, T1 (50 g alum $+50 \mathrm{~g} \mathrm{AlCl}_{3}$ per $\mathrm{kg}$ duck litter) should be recommended as optimum rate due to higher costs with T2 and T3 with little additional benefit over T1. At the least, T2 should be recommended over T3. In addition, $\mathrm{NH}_{3}$ concentration data do not follow the same pattern as $\mathrm{pH}$ data (Figure $1 \mathrm{~A}$ ). $\mathrm{NH}_{3}$ emissions are controlled by $\mathrm{pH}$, but $\mathrm{pH}$ is highly variable. For example, $\mathrm{T} 1 \mathrm{pH}$ was higher than all other treatments at day 28 , but was not different from other $\mathrm{Al}$ treatments at day 38. Typically, $\mathrm{pH}$ increases with time for all treatments, including alum/ $\mathrm{AlCl}_{3}$ treatments. At present, an exact explanation for this variability is not clear. Obviously, litter amendment as acidulants can control $\mathrm{NH}_{3}$ through decreasing litter $\mathrm{pH}$ and minimizing the $\mathrm{NH}_{4}^{+}$to $\mathrm{NH}_{3}$ conversion ( $\mathrm{Li}$ et al., 2008).

In general, litter $\mathrm{pH}$ plays one of the most important roles in regulating $\mathrm{NH}_{3}$ concentration (Li et al., 2008), and it has been shown that $\mathrm{NH}_{3}$ concentration is low at $\mathrm{pH}<$ 7.0 and increases at $\mathrm{pH}>8.0$ (Chung et al., 2015). Given that previous research has shown that poultry that have been exposed to high levels of atmospheric $\mathrm{NH}_{3}$ can show decreased growth rates, feed efficiency, and egg production (Moore et al., 1995; 2000). the $\mathrm{NH}_{3}$ concentration reductions observed in the present study clearly indicate a potentially positive effect on growth performance (Table 1), which can be attributed to the $\mathrm{pH}$-lowering effects of the added acidulants (a combination of alum and $\mathrm{AlCl}_{3}$ ). Interestingly, lower litter $\mathrm{pH}$ has advantages in addition to decreasing $\mathrm{NH}_{3}$ concentration and increasing growth performance.

Our study is the first to examine variation in the growth-promoting effects of an HC/FRK blend in ducks when delivered through different formulations (powder, 
OPEN OACCESS

pellet, coated pellet). On the basis of the growth performance data, we suggest that the mixture developed here is potentially suitable as a duck feed additive. Finally, each of our three litter treatments decreased litter $\mathrm{pH}$ values and $\mathrm{NH}_{3}$ concentrations over time.

\section{CONCLUSIONS}

Results from this study indicated that all these treatments improved duck performance over the control as well as reducing ammonia concentrations. The beneficial effects observed here suggest that pellets or coated pellets of $1 \%$ $\mathrm{HC} / \mathrm{FRK}$ as propose feed were effective for improving the growth performance of ducks. Especially, adding a combination of $50 \mathrm{~g}$ alum and $50 \mathrm{~g} \mathrm{AlCl}$ to $\mathrm{kg}$ duck litter should be recommended as optimum rate due to higher costs with treatment $(100 \mathrm{~g}$ or $150 \mathrm{~g}$ alum $+100 \mathrm{~g}$ or $150 \mathrm{~g} \mathrm{AlCl}$ ) with additional benefits. Additional $\mathrm{Al}$ could improve certain feed parameters, but costs associated with additional inputs must be carefully considered.

\section{ACKNOWLEDGEMENTS}

This work (Grants No.C0394832) was supported by Business for Cooperative R\&D between Industry, Academy, and Research Institute funded Korea Small and Medium Business Administration in 2016.

\section{CONFLICT OF INTERESTS}

No potential conflict of interest was reported by the authors.

\section{AUTHORS CONTRIBUTION}

Woo-Whan, Jang and Tae-Ho, Chung contributed equally to this study as first author for analyzing the data and revising the manuscript. In Hag, Choi as corresponding authors supervised the experiment and wrote the manuscript.

\section{REFERENCES}

-Aniya Y, Ohtani II, Higa T, Miyagi C, Gibo H, Shimabukuro M, Nakanish H, Taira J (2000). Dimerumic acid as an antioxidant of the mold, Monascus anka. Free Radic. Biol. Med. 28(6):999-1004. https://doi.org/10.1016/S08915849(00)00188-X

- Bauer R, Proebstle A, Lotter H (1996). "Cyclooxygenase Inhibitory Constituents from Houttuynia cordata”. Phytomedicine. 2(4):305-308. https://doi.org/10.1016/ S0944-7113 (96) 80073-0

- Choi IH, Moore PAJr (2008). Effects of liquid aluminum chloride additions to poultry litter on broiler performance, ammonia emissions, soluble phosphorus, total volatile fatty acids, and nitrogen contents of litter. Poult. Sci. 87(10):1955-
Advances in Animal and Veterinary Sciences

63. https://doi.org/10.3382/ps.2008-00053

- Chung TH, Choi IH (2015). Influence of Houttuynia cordata powder on the growth performance of ducks and the impact of $\mathrm{AlCl}_{3}$ treatment on ammonia flux in duck litter.J. Environ. Sci. Int. 24(10):1309-1313. https://doi.org/10.5322/ JESI.2015.24.10.1309

- Chung TH, Park C, Choi IH (2015). Effects of Korean red ginseng marc with aluminum sulfate against pathogen populations in poultry litters. J. Ginseng. Res. 39(4):414417. https://doi.org/10.1016/j.jgr.2015.06.005

- Costa LB, Luciano FB, Miyada VS (2013). Herbal extracts and organic acids as natural feed additives in pig diets. S. Afr. J. Anim. Sci. 43(2):181-193. https://doi.org/10.4314 /sajas. v43i2.9

-Darwish AZ, Darwish SM, Ismail MA (2017). Utilization of fermented yeast rice by the fungus Monascus ruber AUMC 4066 as food coloring agents. J. Food. Process. Technol. 8:18. https://doi.org/10.4172/2157-7110.1000645

-David B, Mejdell C, Michel V, Lund V, Moe RO (2015). Air quality in alternative housing systems may have an impact on laying hen welfare. Part II-ammonia. Animals (Basel). 5(3):886-896. https://doi.org/10.3390/ani5030389

- Favero A, Maiorka A, Dahlke F, Meurer RFP, Oliveira RS (2009). Sens RF. Influence of feed form and corn particle size on the live performance and digestive tract development of turkeys. J. Appl. Poult. Res. 18(4):772-779. https://doi. org/10.3382/japr.2009-00069

- Fu J, Dai L, Lin Z, Lu H (2013). Houttuynia cordata Thunb: A Review of Phytochemistry and Pharmacology and Quality Control. Chin. Med. 4(3):101-123. https://doi.org/10.4236 $/ \mathrm{cm} .2013 .43015$

- Fujimoto M, Tsuneyama K, Chen SY, Nihida T, Chen JL, Chen, YC (2012). Study of the effects of Monacolin K and other constituents of red yeast rice on obesity, insulinresistance, hyperlipidemia, and nonalcoholic steatohepatitis using a mouse model of metabolic syndrome. Evid Based. Complement. Altern. Med. 2012:1-11. http://dx.doi. org $/ 10.1155 / 2012 / 892697$

- Jang IS, Ko YH, Yang HY, Ha JS, Kim JY, Kang SY, Yoo DH, Nam DS, Kim DH, Lee CY (2004). Influence of essential oil components on growth performance and the functional activity of the pancreas and small intestine in broiler chickens. Asian-Australas J. Anim. Sci. 17(3):394-400. https://doi.org/10.5713/ajas.2004.394

-Jiang XL, Cui HF (2004). Different therapy for different types of ulcerative colitis in China. World. J. Gastroenterol. 10(10):1513-1520. https://doi.org/10.3748/wjg.v10. i10.1513

-Karáskoá K, Sucgý P, Straková E (2015). Current use of phytogenic feed additives in animal nutrition: a review. Czech. J. Anim. Sci. 60(12):521-530. https://doi. org/10.17221/8594-CJAS

-Lee GD, Kim SC, Choi IH (2013). Using anhydrous aluminum chloride with calcium Carbonate to reduce ammonia volatilization and increase nitrogen content from poultry litter. J. Poult. Sci. 50(2):172-176. https://doi.org/10.2141/ jpsa.0120139

-Lee JS, Kim IS, Kim JH, Kim JS, Kim DH, Yun CY (2008). Suppressive effects of Houttuynia cordata Thunb (Saururaceae) extract on Th2 immune response. J. Ethnophar. macol. 117(1):34-40. https://doi.org/10.1016/j.jep.2008.01.013

- Li H, Xin H, Liang Y, Burns RT (2008). Reduction of ammonia emissions from stored laying hen manure through topical 
application of Zeolite, $\mathrm{Al}^{+}$Clear, Ferix-3, or poultry litter treatment. J. Appl. Poult. Res. 17(4):421-431. https://doi. org/10.3382/japr.2007-00076

-Lu HM, Liang YZ, Yi LZ, Wu XJ (2006). Anti-inflammatory effect of Houttuynia cordata injection. J. Ethnopharmacol. 104(1-2):245-249.

https://doi.org/10.1016/j. jep.2005.09.012

- Miles DM, Miller WW, Branton SL, Maslin WR, Lott BD (2006). Ocular responses to ammonia in broiler chickens. Avian Dis. 50(1):45-49. https://doi.org/10.1637/7386052405R.1

- Moore PAJr, Daniel TC, Edwards DR, Miller DM (1995). Effect of chemical amendments on ammonia volatilization from poultry litter. J. Environ. Qual. 24(2):294-300. https:// doi.org /10.2134/jeq 1995.00472425002400020012x

- Moore PAJr, Daniel TC, Edwards DR (2000). Reducing phosphorus runoff and inhibiting ammonia loss from poultry manure with aluminum sulfate.J.Environ. Qual.29(1):37-49. https://doi.org/10.2134/jeq2000.00472425002900010006x

- Mountzouris KC, Paraskevas V, Tsirtsikos P, Palamidi I, Steiner T, Schatzmayr G, Fegeros K (2011). Assessment of a phytogenic feed additive effect on broiler growth performance, nutrient digestibility and caecal microflora composition. Anim. Feed. Sci. Technol. 168(3-4):223-231. https://doi.org/10.1016/j.anifeedsci.2011.03.020

- Muluye RA, Bian YH, Alemu PN (2014). Anti-inflammatory and antimicrobial effects of heat-clearing chinese herbs: a current review. J. Tradit. Complement. Med. 4(2):93-98. https://doi.org/10.4103/2225-4110.126635

- Naeemasa, M, Alaw Qotbi AA, Seidavi A, Norris D, Brown D, Ginindza M (2015). Effects of coriander (Coriandrum sativum L.) seed powder and extract on performance of broiler chickens. S. Afr. J. Anim. Sci. 45(3):371-378. http:// doi.org/10.4314/SAJAS.V45I4.3

- Olanrewaju HA, Miller WW, Maslin WR, Thaxton JP, Dozier WA, Purswell J, Branton SL (2007). Interactive effects of ammonia and light intensity on ocular, fear and leg health in broiler chickens. Int. J. Poult. Sci. 6(10):762-769. http://doi. org/10.3923/ijps.2007.762.769

- Paraskeuas V, Fegeros K, Palamidi I, Hunger C, Mountzouris, KC (2017). Growth performance, nutrient digestibility, antioxidant capacity, blood biochemical biomarkers and cytokines expression in broiler chickens fed different phytogenic levels. Anim. Nutr. 3(2):114-120. http://doi. org/10.1016/j.aninu.2017.01.005

- Pokharel B (2010). Ammonia Emission from Poultry Industry, its Effects and Mitigation Mechanism, International Veterinary Students Association's Newsletter, December.

- Rao RR, Platel K, Srinivasan K (2003). In vitro influence of spices and spice-active principles on digestive enzymes of rat pancreas and small intestine. Nahrung 47(6):408-412. http://doi.org/10.1002/food.200390091

- Saha M, Chowdhury SD, Hossain Md E, Islam Md K, Roy B (2011). Organic water additive on growth performances, hematological parameters and cost effectiveness in broiler production.J. Anim. Sci. Technol.53(6):517-523. http://doi. org/10.5187/JAST.2011.53.6.517

- SAS (2000). SAT/STAT Software for PC. Release 8.2, SAS Institude Inc., Cary, NC, USA

- Singh MK, Gupta RJ, Singh CS, Paswan VK, Rawat SK (2017). Effect of herbal antioxidant supplementation on the performance of broiler chicks. Environ. Ecol. 35(2):12011204.

-Stanley VG, Gray C, Daley M, Krueger WF, Sefton AE (2004). An alternative to antibiotic-based drugs in feed for enhancing performance of broilers grown on Eimeria spp.-infected litter. Poult. Sci. 83(1):39-44. http://doi. org/10.1093/ps/83.1.39

- Su YC, Wang JJ, Lin TT, Pan TM (2003). Production of the secondary metabolites $\gamma$-aminobutyric acid and monacolin K by Monascus. J. Ind. Microbiol. Biotechnol. 30(1):40-46. http://doi.org/10.1007/s10295-002-0001-5

-Toda S (2005). Antioxidative effects of polyphenols in leaves of Houttuynia cordata on protein fragmentation by copperhydrogen peroxide in vitro. I. Med. Food. 8(2):266-268. https://doi.org/10.1089/jmf.2005.8.266

-Windish W, Schedle K, Plitzner C, Kroismayer A (2008). Use of phytogenetic products as feed additives for swine and poultry. J. Anim. Sci. 86(14 Suppl):140-148. https://doi.org /10.2527/jas.2007-0459

-Yan L, Meng QW, Kim IH (2011). The effects of dietary Houttuynia cordata and Taraxacum officinale extract powder on growth performance, nutrient digestibility, blood characteristics and meat quality in finishing pigs. Livest. Sci. 141(2-3):188-193. https://doi.org/10.1016/j. livsci.2011.05.017 